\title{
Molecular identification of root nodule bacteria from edible crops of Fabaceae family, Kerala
}

\section{S. Darsha}

Department of Sudies in Microbiology, Mangalore University, PG Centre, Jnana Kaveri Campus, Kodagu- 571232 (Karnataka), India

R.Arivukarasu

Department of Pharmacognosy, KMCH College of Pharmacy, Coimbatore-641014 (Tamil Nadu), India

\section{Jayashankar}

Department of studies in Microbiology, Mangalore University, PG Centre, Jnana Kaveri Campus, Kodagu- 571232 (Karnataka), India

Mohammed A. Saeed*

Department of studies in Microbiology, Mangalore University, PG Centre, Jnana Kaveri Campus, Kodagu- 571232 (Karnataka), India

*Corresponding author. E-mail: binabood11@yahoo.com

\begin{abstract}
The root nodule bacteria were isolated from three different leguminous plants belonging to the Fabaceae family such as Cajanus cajan, Lablab purpureus and Vigna unguiculata using YEMA medium and identified. The isolates were submitted to $16 S$ rRNA and PCRRFLP typing. A representative sample was further submitted to sequence analysis of $16 \mathrm{~S}$ rRNA. Isolates were assigned to two genera and were related to Rhizobium spp. $(75 \%)$ and Bacillus spp. (25\%) respectively. This study opens the doors to researchers to do specific studies on this root nodule bacteria which are symbiotic with these legume plants in this area for their antibacterial activity, medicine and food application, and sustainable agriculture. Rhizobium and other beneficial microbes may be used as biofertilizers as a substitute for chemical fertilizers.
\end{abstract}

Keywords: Fabaceae, Isolation, Leguminous, PCR-RFLP, Root nodule bacteria, $16 S$ rRNA

\section{INTRODUCTION}

In some plants, especially legumes, the bacteria live in small outgrowths on the roots called nodules. The plant roots supply vital minerals and newly produced substances to the bacteria (Dariel and John, 2003). Inside these nodules, the bacteria do nitrogen fixation and the plant absorbs it in the form of ammonia. The soluble form of nitrite and nitrate can be adjusted by plant's roots and used in creating proteins and nucleic acids. This form of nitrogen is usually transformed to ammonia by plants, animals and microorganisms (Robertson, and Groffman, 2015 ). Rhizobium and Bradyrhizobium are designated as soil bacteria that have ability to taint root hair of leguminous plants and it to encourage nodule formation with following fixation ofnitrogen. Nitrogen fixing food and silage legumes lenient of environmental pressures denote an important strategy to recover agricultural productivity. The biological nitrogen fixation, because of root nodule bacteria, legume symbiosis benefits not only the host crop but also the subsequent crops in that field. It may also act

\section{Article Info}

DOI:10.31018/jans.v10i3.1864

Received: August 12, 2018

Revised: August 23, 2018

Accepted: August 26, 2018

\section{How to Cite}

Darsha, S. et al. (2018)

Molecular identification of root nodule bacteria from edible crops of Fabaceae family, Kerala. Journal of Applied and Natural Science, 10(3): 1063-1065 as a non-symbiotic PGPB as in the case of certain non-legume crops such as rice or wheat, which are the best-studied examples that benefit from root nodule bacteria as endophytes (Biswas et al., 2000). For all these reasons, the root nodule bacteria -legume symbiosis has been widely studied as a model of mutualistic associations and as a beneficial association for sustainable agriculture. With increasing use of Rhizobium and other beneficial microbes as bio fertilizers, reduction in the need for chemical fertilizers can be observed. Therefore, bio fertilization has great importance in decreasing environmental pollution and deterioration of nature (Vessey, 2006; Erman et al., 2011). The inoculation of seeds with Rhizobium is known to increase nodulation, $\mathrm{N}$ uptake, growth and yield parameters of legume crops (Erman et al., 2011). Other study outlined the potential participation of legume nodules in increasing risks related to human pathogens (Muresu, 2010). In the present study, the root nodule bacteria from three leguminous plants such as Cajanus cajan, Lablab purpureus and Vigna unguiculata of the family Fabaceae, were isolated and identified. 


\section{MATERIALS AND METHODS}

Collection and extraction of nodulated roots of legumes: The nodulated roots of $C$. cajan and $V$. unguiculata were collected from the paddy fields of Thiruvalathur region, Palakkad, Kerala, India, $10.74^{\circ} \mathrm{N}, 76.69^{\circ} \mathrm{E}$. These plants were cultivated as mixed cropping and $L$. purpureus was cultivated as domesticated plant from the same area. The roots were first washed thoroughly with sterile distilled water and nodules were surface sterilized by washing with $95 \%$ ethanol for 10 seconds and again washed in sterile distilled water for about 5 times. Roots were mashed with pestle mortar to obtain nodules and milky white substances of bacteroids by dipping in phosphate buffer solution.

PCR-RFLP and sequencing analysis: PCRRFLP of the 16S rRNA genes was conducted for the 51 isolates using the restriction endonucleases Mspl and Ndell according to (Mhamdi et al., 2002). Representative isolates of the different ribotypes were selected for nearly full-length sequencing of the 16S rRNA gene according to (Sardi et at., 2011). The sequence obtained from isolates were matched with the nucleotide database available at the Gene Bank, using BLAST program.

\section{RESULTS}

In the present study, strains of root nodulating bacteria are isolated from the root nodules of $C$. cajan, $L$. purpureus and $V$. unguiculata plants growing in Thiruvalathur Region, Palakkad, Kerala, India (Fig. 1).

A collection of 51 strains isolated from surfacesterilized root-nodules of C. cajan, L. purpureus, and $V$. unguiculata plants nodules were first investigated with PCR- RFLP of $16 \mathrm{~S}$ rRNA genes. All the Isolates belonged to the two genera Rhizobium spp., and Bacillus spp., having similarity of 75 $\%$ and $25 \%$ respectively (Table 1 ). The three representative isolates of the dominant ribotype A (49 $\%$ of total isolates) showed $(99.70 \%)$ sequence identity with the type strain of Rhizobium leguminosarum (USDA 2370). When re-examined for

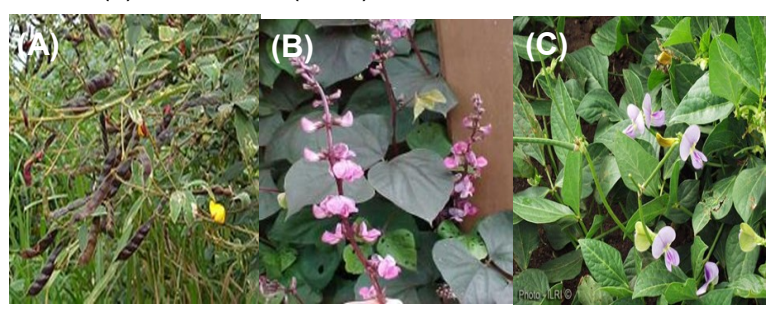

Fig. 1. Legumes plants, A: Cajanuscajan (Pigeon Pea), B: Lablab purpureus (HycinthBean) C: Vigna unguiculate (Cow Pea).

nodulation, all members of ribotype $A$ induced nodules on $C$. cajan, $L$. purpureus, and $V$. unguiculata plants. Non-symbiotic rhizobia lacking symbiotic genes (ribotypes B, C, D, and E) were also frequently isolated in 13 strains, their closest respective relatives, such as $R$. grahamii, $R$. huautlense, $R$. albertimagni (formerly Agrobacterium albertimagni), $R$. nepotum, and $R$. pusense (formerly Agrobacterium tumefaciens genomovar), then Bacillus (ribotypes F, G, and $\mathrm{H}$ ) were also frequently isolated in 13 strains approximately $25 \%$ of total isolates their closness to $B$. megaterium, B. muralis, and B. subtilis. (Table 1).

\section{DISCUSSION}

C. cajan and L. purpureus are grown as a pulse crop (crop harvested for dry seed) or eaten green as a vegetable. The grain is popularly consumed in India, Asia, and Africa. India is the largest importer and producer (Phatak et al., 1993; Maass et al., 2010). V. unguiculata is commonly cultivated as a nutritious and highly palatable food source in the southern United States, Middle East, Africa, Asia, and throughout the tropics and subtropics. The seed is reported to contain $24 \%$ crude protein, $53 \%$ carbohydrates and $2 \%$ fat (FAO,2012). The leaves and flowers can also be consumed. These crops are usually well nodulated in Indian soils; however, there are much studies about the diversity and the effectiveness of the nodulating rhizobia. Hence, special interest has been focused on microbial diversity of three plants. A unique isolate

Table 1. Identification of the bacteria using $16 \mathrm{~S}$ rDNA gene of the bacterial isolates present in the nodules of the plants C. cajan, L. purpureus and V. unguiculate.

\begin{tabular}{|c|c|c|c|c|c|c|}
\hline $\begin{array}{l}\text { Ribotype }^{a} \\
\text { (RFLP) }\end{array}$ & $\begin{array}{l}\text { Strain } \\
\text { Accession }\end{array}$ & $\begin{array}{l}\text { Accession } \\
\text { number }\end{array}$ & Closest relative species & $\begin{array}{l}\text { Similarity } \\
(\%)\end{array}$ & $\begin{array}{l}\text { Nodulation } \\
\text { ability }\end{array}$ & $\begin{array}{l}\text { Amplifica- } \\
\text { tion of nifH }\end{array}$ \\
\hline \multirow[t]{3}{*}{ A (25) } & FB1006 & JN558659 & $\begin{array}{ll}\text { Rhizobium } & \text { leguminosarum } \\
\text { USDA2370 }\end{array}$ & 99.70 & + & + \\
\hline & FB14022 & JN558660 & R.leguminosarum USDA2370 & 99.70 & + & + \\
\hline & FB14022 & JN558660 & R.leguminosarum USDA2370 & 99.70 & + & + \\
\hline B (1) & FB803 & JX943843 & R. grahamii CCGE 502 & 100 & - & - \\
\hline \multirow[t]{2}{*}{ C (3) } & FB2501 & JX943844 & R. huautlense $\mathrm{SO} 2$ & 100 & - & - \\
\hline & FB11041 & JX943845 & R. albertimagni AOL15 & 99.80 & - & - \\
\hline \multirow[t]{2}{*}{ D (7) } & FB1802 & HM194623 & R. nepotum LMG26435 & 100 & - & - \\
\hline & FB19011 & HQ007644 & R. nepotum LMG26435 & 99.90 & - & - \\
\hline$E(2)$ & FB17031 & HQ007645 & R. pusense NRCPB10 & 99.90 & - & - \\
\hline$F(8)$ & FB1502 & JX943846 & $\begin{array}{l}\text { Bacillus megaterium IAM } \\
13418\end{array}$ & 98.50 & - & - \\
\hline G (1) & FB705 & JX943855 & B. muralis LMG 20238 & 98.50 & - & - \\
\hline H (4) & 1FB2005 & JX943862 & $\begin{array}{l}\text { B. subtilis subsp. subtilis } \\
\text { DSM } 10\end{array}$ & 97.90 & - & - \\
\hline
\end{tabular}

${ }^{a}$ Total number of isolates in each ribotype is indicated between parentheses. 
representing the major colony-morphology phenotype was retained for each nodule analyzed. Only 49 $\%$ of isolates were able to re-nodulate their original host. They were almost closely related to $R$. leguminosarum. However, a high percentage of isolates (55\%) could not nodulate $V$. faba and either L. culinaris. The most frequent were non-symbiotic rhizobia, mainly taxa formerly known as agrobacteria (25 $\%)$, and taxa associated to Pseudomonas (16\%) and Enterobacter (16\%), which have been commonly isolated from root-nodules of several legumes (Lajudie et al., 1999; Ibanez et al., 2009; Ramezanpour, 2011). These results agree with the studies carried out in India (Rajeswari et al., 2017; Wadhwa et al., 2017). The results found from the examination of nodulation displayed that all the strains have been able to nodule their host plants. Some authors have studied the symbiotic parameters of diverse strains nodulating the $L a b$ lab for the collection of couples of rhizobia - Lablab of high symbiotic act (Kurlovick et al., 1997). The selection of performant symbiotic couples of Lablab and their microsymbiotes can rise the profit of the symbiosis (Younes et al., 2005).

\section{Conclusion}

Bacteria isolated from root-nodules of $C$. cajan, $L$. purpureus and $V$. unguiculata grown in different Kerala soils were diverse and could be affiliated to much genera, including $R$. leguminosarum and other Rhizobium spp. However, other endophytes included taxa identified as human pathogens, rising the concern of the hazards posed by pathogens. These crops are usually well nodulated in Indian soils. In this study, a special interest has been engrossed on microbial diversity of three legumes plants that would help as biofertilizers for the crop of the area.

\section{ACKNOWLEDGEMENTS}

The authors warmly thank Pharmaceutical Biotechnology Laboratory in KMCH College of Pharmacy, Coimbatore, Tamil Nadu for its collaboration and for help in the analysis of samples.

\section{REFERENCES}

1. Biswas, J.C., Ladha, J.K., Dazzo, F.B., Yanni, Y.G. and Rolfe, B.G. (2000). Rhizobial inoculation influences seedling vigor and yield of rice. Agron J., 92 : 880-86.

2. Dariel, B. and John, G. (2003). Rhizobium, A Manual for Basic Practical Microbiology, Society for General Microbiology, London.

3. Lajudie, P., Willems, A., Nick, G., Mohamed, T.S., Torck, U., Filali- Maltouf, A., Kersters, K., Dreyfus, B., Lindstrom, K. and Gillis, M. (1999). Agrobacterium bv.1 strains isolated from nodules of tropical legumes. Syst. Appl. Microbiol., 22:119-132.
4. Erman, M., Demir, S., Ocak, E., Tufenkci, S., Oguz, F. \& Akkopru, A. (2011). Effects of Rhizobium, arbuscular mycorrhiza and whey applications on some properties in chickpea (Cicer arietinum L.) under irrigated and rainfed conditions: Yield, yield components, nodulation and AMF colonization. Field Crops Res., 122 (1), $14-24$.

5. FAO.(2012). Grassland species index. Cajanus cajan.

6. Ibanez F, Angelini J, Taurian T, Tonelli ML, Fabra A (2009). Endophytic occupation of peanut root nodules by opportunistic Gamma proteobacteria. Syst. Appl. Microbiol., 32:49-55

7. Kurlovick, B.S, et al., (1997). Stress tolerance in Rhizobium and Bradyrhizobium, and nodulation under adverse soil conditions. Canadian Journal of Microbiology, 38, 475-484.

8. Maass, B.L., M.R. Knox, S.C. Venkatesha, T.T. Angessa, S. Ramme, and B.C. Pengelly. (2010). L. purpureus-a crop lost for Africa? Trop. Plant Biol., 3 (3):123-135. doi:10.1007/s12042-010-9046-1

9. Mhamdi R, Laguerre G, Aouani ME, Mars M, Amarger $N$ (2002). Different species and symbiotic genotypes of field rhizobia can nodulate Phaseolus vulgaris in Tunisian soils. FEMS Microbiol. Ecol., 41:77-84.

10.Muresu R, Maddau G, Delogu G, Cappuccinelli P, Squartini A (2010). Bacteria colonizing root nodules of wild legumes exhibit virulence-associated properties of mammalian pathogens. Antonie Van Leeuwenhoek, 97:143-153.

11.Phatak, S.C., R.G. Nadimpalli, S.C. Tiwari, and H.L. Bhardwaj. (1993). Pigeonpeas: potential new crop for the southeastern United States. In: J. Janick and J.E. Simon, editors, New Crops. Wiley, New York. p.597-599.

12.Rajeswari P., Aishwaryaalakshmi B. Jeyagowri C. (2017). Isolation, identification and screening of Rhizobium for plant growth promotion. Int. J. of App. Res., 2017; 3(1): 732-733.

13.Ramezanpour, M.R. (2011). Biochemical characteristics and genetic diversity of fluorescent pseudomonads isolated from rice rhizosphere in north of Iran. Am. Eurasian J. Agric. Environ. Sci., 10:180-185.

14.Robertson, G and Groffman P.(2015). Nitrogen transformations In: Soil microbiology, ecology and biochemistry, E. A. Paul, editor. Fourth edition. Academic Press, Burlington, Massachusetts, USA. Pages 421-446.

15.Saıdi S, Mnasri B, Mhamdi R (2011). Diversity of nodule endophytic agrobacteria-like strains associated to different grain legumes in Tunisia. Syst. Appl. Microbiol., 34: 524-530.

16.Vessey, J.K. and Chemining'wa, G.N. (2006). The genetic diversity of Rhizobium leguminosarum bv. viciae in cultivated soils of the eastern Canadian prairie. Soil Biol. Biochem., 38 : 153-163.

17.Wadhwa1 Z., Srivastava V., Rani R., Tanvi, Makkar K. and JangraS.(2017) Isolation and Characterization of Rhizobium from Chickpea (Cicer arietinum) Int. J. Curr. Microbiol. App. Sci., 6 (11): 2880-2893

18. Younes, R.E, et al., (2005). Identification of Rhizobium-specific intergenic mosaic elements within an essential two-component regulatory system of Rhizobium species. Journal of Bacteriology, 177 : 54855494. 